\title{
Propaganda, Kamu Diplomasisi ve Nesnellik Sarkacında Uluslararası Yayıncılık: Geçişkenlik Ekseninde Bir İ̧̧levler Dizisi
}

\author{
Onur Bekiroğlu (Doç. Dr.) \\ Ondokuz Mayıs Üniversitesi İletişim Fakültesi \\ onur.bekiroglu@omu.edu.tr \\ Orcid: 0000-0002-4526-358X
}

Başvuru Tarihi: 21.10.2018

Yayına Kabul Tarihi: 13.11.2018

Yayınlanma Tarihi: 21.01.2019

Öz

Devletler tarafından örtük veya açık biçimlerde desteklenen bir yayın faaliyeti olan uluslararası yayıncılık, uluslararası iletişimin şekillenmesinde önemli bir tarihsel pratiğe işaret etmektedir. Bu yayıncllık türü, tecimsel uluslararası medya kategorisinden öncelikli hedef kitlesi ve sahiplik gibi açılardan farklılaşmakla birlikte uluslararası iletişim alanının şekillendirilmesi ve ilgili devletlerin bakış açılarını yansıtma gibi noktalarda kimi zaman örtüşmektedir. 20. yüzyılın ilk yarısında kısa dalga radyo üzerinden bașlayan uluslararası yayıncılık, 1980'lerin ortalarından itibaren uydu televizyonu ile devam etmiştir. 1990'lı yıllarda internetin aşama aşama belirleyici bir aktör olarak kitle iletişimi ortamına dahil olmasıyla birlikte uluslararası yayıncılık için yeni bir mecra daha açılmıştır. 21. yüzyıla gelindiğinde ise internetle birlikte, sunduğu imkân ve potansiyeller ile iletişim ortamını dönüştüren sosyal medya, uluslararası yayıncılığın anlam, kapsam ve işlev dünyasını da önemli ölçüde etkilemiştir. Başlangıçta, içinde hayat bulduğu dönemin sosyo-politik atmosferinin de etkisiyle propagandayla özdeşleşen uluslararası yayıncılık, zaman içinde iletişim ortamının çeşitlenmesi ve giderek merkezkaç özellik kazanmasıyla birlikte hem kamu diplomasisi enstrümanı olarak işlevselleşme hem de nesnellik, çok yönlülük, dengelilik, doğruluk gibi geleneksel gazetecilik idealleri/ilkeleriyle daha fazla örtüşme yönünde bir opsiyonla karşı karşıya kalmıştır. İlk dönemlerdekinden farklılaşan bu işlevsellikler, hem bir tercih alanına işaret etmekte hem de yer yer bir zorunluluk olarak kendini dayatmaktadır. Özellikle, kullanıcıları içerik üreticisi ve yayımcısı olarak iletişim ortamına dahil eden sosyal medyanın bu anlamda dönüştürücü bir motivasyonu dayattığ da söylenebilir. Bu perspektiften hareketle; söz konusu çalıșmada literatür taramasına dayalı olarak uluslararası yayıncılık, bu yayıncılık faaliyetine içkin işlevler, değerler, kodlar ve pratikler örgüsü çerçevesinde tartışmaya açılmaktadır. Ayrıca, uluslararası yayıncılığın kamu diplomasisi olgusuyla kesişim noktaları ele alınmakta ve yeni iletişim teknolojilerinin karakterize ettiği bir dönemde uluslararası yayıncılığın önündeki değişim alanları irdelenmektedir. Bu bağlamda uluslararası yayıncılığın işlev ve kodları, bir analojiyle bir ucunda propaganda, ortasında kamu diplomasisi ve diğer ucunda nesnellik idealinin olduğu bir sarkaç hareketiyle açıklanabilir. Bu sarkacın hareketlerine rengini veren temel dinamiklerden biri ise söz konusu işlevler arasında geçişkenliklerin yaşanabilmesidir.

Anahtar Kelimeler: Uluslararası Yayıncılık, Propaganda, Kamu Diplomasisi, Nesnellik, Geçişkenlik. 


\title{
International Broadcasting within
} the Pendulum of Propaganda, Public Diplomacy and Objectivity: A Series of Functions within The Axis of Transitivity

\author{
Onur Bekiroğlu (Assoc. Prof. Dr.) \\ Ondokuz Mayıs University Faculty of Communication \\ onur.bekiroglu@omu.edu.tr \\ Orcid: 0000-0002-4526-358X
}

Date Received: 21.10.2018

Date Accepted: 13.11.2018

Date Published: 21.01.2019

\begin{abstract}
International broadcasting, an activity that is implicitly or explicitly supported by States, has historically had an important place in shaping international communication. Although this type of broadcasting differs from the commercial international media category in terms of its preferred target group and ownership, it has some common points with the abovementioned category in terms of shaping the international communication field and reflecting the perspectives of the related states. International broadcasting, which began in the first half of the 20th century with shortwave radio, continued with satellite television since the mid-1980s. As internet was slowly appearing as a dominant actor in mass communication environment in the 1990s, a new channel was opened for international broadcasting. In the 21st century, social media as a part of internet transformed the communication environment with the opportunities and potentials it offers and international broadcasting was affected in terms of meaning, scope and function. At the beginning, international broadcasting has been identified with propaganda due to the socio-political atmosphere of the period in which it came to life. However, in time, as international broadcasting became less dependent to states, it started being regarded as an instrument of public diplomacy and a tool overlapping more with the traditional journalistic ideals/principles such as objectivity, versatility, balance and accuracy. Together with the propaganda function which was initially regarded as the basic function of international broadcasting, public diplomacy and the ideal of objectivity have also started to be perceived as the other functions of it. Public diplomacy and the ideal of objectivity, contrary to propaganda function amount to both a chance to choose and realm of necessity. In particular, it can be said that the social media, which includes users as the content producer and publisher, imposes a transformative motivation in this sense. From this perspective; based on the literature review in this study, international broadcasting will be discussed within the framework of the functions, values, codes and practices inherent in this activity. Moreover, the common points between international broadcasting and public diplomacy will be considered as well as addressing the possible changes of international broadcasting in an era characterized by new communication technologies. In this context, the functions of international broadcasting can be explained an analogy by three swings on a pendulum with propaganda at one end, public diplomacy in the middle and an ideal of objectivity at the other. That the pendulum can swing between the above-mentioned functions in transitivity can be considered as the most important thing to understand pendulum's motions.
\end{abstract}

Keywords: Internatonial Broadcasting, Propaganda, Public Diplomacy, Objectivity, Transitivity. 


\section{Giriş}

Yerel, bölgesel ve ulusal düzlemlere konu olan yayıncılık faaliyeti, uluslararası boyutta da uluslararası ilişkilerin çatışma, mücadele, müzakere, diyalog gibi çeşitli görünümleriyle bağlantılı olarak işleyen bir iletişim süreci olarak gerçekleşmektedir. Bu bağlamda, uluslararası yayıncılık; dünya savaşları ve Soğuk Savaş ile birlikte kimi zaman açık kimi zaman da örtük biçimlerde propagandayla örtüșen bir bağlamda gelișmeye başlamış ve özellikle Soğuk Savaş sonrası süreçte devletlerin diplomasi alanında işlevsel olarak kullanabildiği bir enstrüman olarak gelişimini sürdürmüştür. $\mathrm{Bu}$ bağlamda özellikle geleneksel diplomasi anlayışından ayrışan bir olguya işaret eden kamu diplomasisi olgusu ile uluslararası yayıncılığın önemli kesişim noktalarına sahip olduğunu söylemek mümkündür. Bir başka deyişle, uluslararası yayıncılık, kamu diplomasisi olgusunun önemli bir faaliyet alanı olarak belirmekte ve kullanılabilmektedir.

Tarihsel süreçteki gelişim seyrinin yanı sıra uluslararası yayıncılık, özellikle günümüzün küresel dünyasında daha yoğun ve çok boyutlu bir hâl almıştır. Küreselleşme olgusu; dünyadaki devletleri, ulusları, toplulukları daha fazla birbirine bağlı ve bağımlı hale getirirken; uluslararası arenayı da tek merkezli olmaktan çlkararak çok aktörlü bir arenaya dönüștürmüștür. Öyle ki; iletişim teknolojilerinin de etkisiyle dünyaya kapalı olma gibi bir seçeneğin imkânsız hâle geldiğini söylemek mümkündür. Bu süreçte, uluslararası yayıncılık faaliyeti de hem hiç olmadığı kadar ivme kazanmış hem de aktörler, habercilik ve iletişim faaliyeti açısından belli bir dönüşüm sürecine girmiştir. Uluslararası yayıncılık faaliyetinin anlaşılabilmesi açısından hayati önemde olan bir başka boyut ise uluslararası iletişimdir. Zira, uluslararası yayıncılık, uluslararası iletişim düzeni içinde işleyen daha spesifik bir alan olarak da değerlendirilebilir. 1970'li yıllarda UNESCO bünyesinde gerçekleşen az gelişmiş ülkelerin Yeni Dünya Enformasyon ve İletişim Düzeni taleplerine yönelik Amerika ve İngiltere'nin karşı çıkışları, uluslararası yayıncılığın da kodlarına yönelik önemli bir veri sunmuştur. Bu bağlamda, o dönemde uluslararası iletişim tek yönlü enformasyon akışı ve propaganda ile karakterize olmuştur. Yeni iletişim düzeni taleplerine yönelik itirazın, serbest enformasyon akışı ilkesi üzerine temellendirilmesi ise uluslararası iletişimin gelişmiş aktörlerin elinde biçimlendiği gerçeğini o dönem için değiştirmemiştir.

Günümüze gelindiğinde; genel olarak iletişim teknolojilerinin çeşitlenmesi ve özel olarak da internet ve sosyal medya gibi kullanıcı üretimi içerik imkânı şeklinde son derece önemli olanaklar sağlayan yeni mecra ve teknolojilerin varlığı, kitle iletişimi açısından da önemli potansiyelleri beraberinde getirmiştir. Uluslararası yayıncılığın da hem biçim ve içerik hem de değerler/kodlar, işlevler ve pratikler bağlamında herhangi bir etkiye maruz kalmaksızın bir önceki yüzyılda olduğu gibi var kaldığını söylemek oldukça zordur. Zira hem kurumsal aktörler hem de bireysel aktörler nezdinde önemli imkânlar sunan teknolojiyle yoğun biçimde aracılanmış böylesine bir iletişim ortamında uluslararası yayıncılığın dönüșüm sürecine girmesi gerektiğinin kaçınılmaz olduğu söylenebilir. Bir başka deyişle, uluslararası yayıncılığın birtakım kod, işlev ve işleyiş biçiminin; bizatihi dönüşmesinden ziyade, insanların bilgiye erişim kanallarının bu denli yoğun olduğu bir küresel iletişim dünyasında bu dönüşümün bir gereksinim olarak kendini dayattığını vurgulamak gerekir. 
Bu çalışma kapsamında uluslararası yayıncılığın tarihsel arka planından kesitler ele alınmakta, uluslararası yayıncılık bu yayıncılık faaliyetine içkin işlevler, değerler, kodlar ve pratikler örgüsü çerçevesinde tartışmaya açılmaktadır. Çalışmada ayrıca uluslararası yayıncılığın kamu diplomasisi olgusuyla kesişim noktaları ele alınmakta, yeni iletişim teknolojilerinin karakterize ettiği bir dönemde uluslararası yayıncılığın önündeki değișim alanları irdelenmekte ve bu yayıncılık türüne yönelik birtakım öneriler getirilmektedir.

\section{Uluslararası Yayıncılığın Tarihsel Arka Planı}

Dünya tarihinin farklı dönemlerinde ve yerlerinde kullanılan iletişim araçları, bir potansiyel olarak o dönemin ölçeğinde uluslararasılaşma imkânlarını barındırsa da uluslararası yayıncılığın yaşam öyküsü, radyonun icadı ve adım adım gelişimiyle koşut bir nitelik taşır. İnsanoğlunun iletişim serüveninde 19. yüzyılın ortalarından itibaren belirmeye başlayan, bu yüzyılın sonlarına doğru teknolojik ve kullanım sınırlarını giderek genișleten radyo, 20. yüzyılın ilk yarısında bir kitle iletişim aracı olarak bu serüvene dahil olmuştur.

Bu gelişim çizgisi içinde bir yayıncılık türü olarak beliren uluslararası yayıncılık kapsamında radyonun politik amaçlar doğrultusunda en erken kullanımı, 1926 yılında Rusya'nın daha önce kendisine ait bir bölge olan Besarabya'yı Romanya'dan geri talep etmek için radyo yayıncılığına başvurması olarak gösterilmektedir. Rusya, aynı zamanda uluslararası radyo yayıncılığını, dış politikasının bir enstrümanı olarak devreye sokan ilk aktör olurken; 1929'da Moskova Radyosu'nun (Radio Moscow) yabancı dillerde programlar bölümü açılmış ve ilk etapta 4 dilde gerçekleşen yayınlar 1933 yılına gelindiğinde 11 dile yükselmiştir. Bu ilk çıkış noktasında ve kullanım örneğinde uluslararası yayıncılığın temel motivasyonu, komünist devrimi daha geniş ölçekte duyurmak ve yaygınlık kazanmasını sağlamak olmuştur (Rawnsley, 2016, 43).

Bu başlangıç aşamasında uluslararası radyo yayıncılığının temel işlevi ve hedefinin, propaganda faaliyetinin icrası ve endoktrinasyon olarak kalın çizgilerle belirdiği görülmektedir. Dünyanın o dönem içinde bulunduğu politik ve toplumsal atmosfer, ideolojik kutupların güç mücadelesi, taraftar kazanma çabası ve çatışmaya doğru sürüklenen süreç, uluslararası yayıncılığın bu ilk evresine kesif biçimde rengini vermiştir.

Öte yandan, konjonktürel etkilerin ötesinde uluslararası yayıncılık faaliyetinin, bizzat doğasında propagandaya yönelik bir işlevi doğuşundan itibaren taşıdığı da öne sürülebilir. Çünkü bu yayıncılık pratiğinde yayıncılık ölçek ve hedefinin değişmesi/ genişlemesi ve "içeriden" ziyade "dışarıya" yönelme durumu; söz konusu dışarının dengelerinin, önceliklerinin, değerlerinin, politik hedeflerinin, stratejilerinin, örgütlenme biçiminin, iletişim sisteminin, toplumsal-iktisadi örüntülerinin vb. çoğu zaman gözetil(e)mediği bir kitle iletişimi icrasına gönderme yapmaktadır.

Radyonun gelişim süreci içinde kısa dalgaların keşfi, ilk etapta performans ve hizmet güvenilirliği noktasında bir kesinlik garantisi veremese de uluslararası yayıncılık olanaklarının önünü açan temel dinamik olmuştur. Amerika'da radyo ile kısa dalga yayıncılığı, daha çok eğlence içerikli yayınları Orta Amerika'ya doğru iletmenin aracı olarak işlev kazanırken; Avrupa'da ise bu motivasyondan farklı bir çizgi üzerinde süreç ilerlemiştir. İletişim alanındaki bu yeni imkân, öncelikle Avustralya ve Kanada gibi uzak kolonilere yayın aracı olarak algılanmakla birlikte, 
1936 yılından itibaren daha farklı bölgelere yönelik propaganda yayınları da devreye sokulmuştur. Bu kapsamda İngiliz kamu yayıncı kuruluşu BBC, söz konusu tarihlerde Arap dünyasına propaganda yayınlarına başlarken, bu yayınlar aynı zamanda bölgede sömürgeci çıkarları bulunan İtalya'nın benzer yayınlarına yönelik bir ön alma çabasını da içermiştir. Bu zaman dilimi, uluslararası yayıncılık ekseninde iki aktörlü ve iki aktörün çarpışan çıkarlarının karşı karşıya geldiği bir zemin olarak işaretlenebilir. Öte yandan çok uzun bir sürece yayılmadan 1939'a gelindiğinde ise Almanya ve Rusya gibi başat aktörler de yeni propaganda tekniklerini sahaya sürmüşlerdir (Wood, 2008, 2).

Uluslararası yayıncılık kulvarında diğer ülkelerdeki gelişmeler de çok geçmeden birbirini takip etmiștir. Örneğin; Hollanda 1928'de, yine 1928'de önce Merkezi Yayıncılık Sistemi ile sahaya giriş yapan Çin daha sonra Uluslararası Çin Radyosu ile 1941'de, Almanya 1929 yılında, Fransa 1931'de, İngiliz kamu yayıncı kuruluşu BBC kendi servisini 1932'de, Japonya 1934'te, Amerika ise bir müddet daha sonra Voice of America ile 1942 yılında uluslararası yayıncılık deneyimini başlatmıştır (Rawnsley, 2016, 43).

Benzer şekilde, yurt dişındaki veya kolonilerindeki vatandaşlarıyla etkileșim hâlinde olmak amacıyla Avusturya 1929 yılında ve Belçika da 1934 yılında uluslararası radyo yayıncılığı sahasında yerini almıştır. Öte yandan, misyonerlik yüklü daha farklı motivasyonlarla Vatikan da 12 Şubat 1931 yılında bu alanda faaliyete geçmek için kısa dalga radyosunu (Vatican Radio) inşa etmiştir. Uluslararası yayıncılık bağlamında Avrupa ve Kuzey Amerika dışındaki gelişmeler görece daha yavaş bir ritimde seyretmiștir. Avustralya' da 1931 yılında inisiyatifi alan ticari bir girișim olan "Amalgamated Wireless" adlı yayıncı kuruluş, güney yarımküredeki dünya çapında ilk düzenli yayın hizmeti olarak tanımlanmıștır. Kendini "Avustralya'nın Sesi” olarak takdim eden ve Avrupa'da ilk etapta güçlü bir yankı bulan bu istasyon, kısa bir süre sonra 1937'de etkinliğini yitirmiștir. Japonya ve Çin ise uluslararası yayıncılık alanına 1930'lu yılların ortalarına kadar tam olarak dahil olmamışken, Tayland ise 1931'de düzenli olmayıp sadece özel günlerde yayın yapan kısa dalga bir radyo istasyonunu kullanmıştır. Afrika'ya bakıldığında da Kenya'da kurulan ilk kısa dalga istasyon ile 1929 yılı uluslararası radyo yayıncılığının miladı olarak kayda geçmiştir. Tüm bu gelişmeler neticesinde, 1930'lu yılların ortaları birçok uluslararası yayıncı kuruluşun düzenli olarak yabancı dillerde programlarını yayınladıkları bir dünya tablosu ortaya çıkmıştır (Bumpus ve Skelt, 1984, 14).

Uluslararası yayıncılık serüveninin ilk yayılım dalgasında Türkiye'nin de bu yeni yayıncılık türünden geri durmadığı ve dünya ile eş zamanlı olarak bu alandaki ilk çabalarını kayda geçirdiği görülmektedir. Bu kapsamda, Türkiye'nin Ankara Radyosu ile 8 Ocak 1937 tarihinde başlayan serüveninde ilk dış yayın, Hatay sorunu ile ilgili dönemin Başbakanı İsmet İnönü'nün konuşmasının Arapçaya çevrilerek antene verilmesi olmuştur. Türkiye'de 1938'in sonlarına doğru düzenli bir hâl alan uluslararası radyo yayıncılığı; Türkçe, İngilizce, Fransızca ve Almanca olmak üzere dört dilde yayın yapmaya başlamıştır. Söz konusu yayınların aktörü olan yayıncı kuruluş, 1963 yılından itibaren “Türkiye’nin Sesi Radyosu” adını almıştır. Bugün gelinen noktada ise "Türkiye'nin Sesi Radyosu" Türkçe dışında 35 yabancı dilde gerçekleştirdiği uluslararası yayınlarını Avrupa'dan Asya, Amerika ve Afrika'ya kadar geniş bir coğrafyaya ulaștırmaktadır (http,//www.turkiyeninsesiradyosu. com, 2018). 
Uluslararası yayıncılığın bu tarihsel döneminde kimi zaman açık kimi zaman örtük biçimde ve çoğu zaman da siyasal ve dini bağlamlarda gerçekleşen propagandayla yoğrulmuş işlev, icra noktasında ise daha belirgin şekilde kendini göstermiştir.

Buna yönelik sıkça referans verilen örneklerden biri de İngiltere'nin Amerika'nın İkinci Dünya Savaşı'na girmesi konusunda zemin hazırlamaya yönelik uluslararası yayıncılık faaliyetleri olmuştur. İngiltere ve mücadelesine ilişkin Amerikan algısının şekillenmesi sürecinde İngiliz hükümetinin ulusal sınırları aşan faaliyetleri ve dönemin İngiltere Başbakanı Winston Churchill'in radyo konuşmaları önemli bir aktör olarak rol oynamıştır. Öyle ki bu konuyla ilgili söz konusu dönemdeki uluslararası yayınlar ve konuyla ilgili haberler ile basın fotoğraflarının, İngiliz propaganda politikasının uyumlu bileşenleri olarak işlev gördüğü belirtilmektedir (Cull, 1995, 4).

Uluslararası radyo yayıncılı̆̆ı, İkinci Dünya Savaşı ve Soğuk Savaş süresince uluslararası propaganda ve kamu diplomasisini domine etmeye devam etmiştir (Rawnsley, 2016, 43). Bu dönemde Amerikan destekli uluslararası yayıncı kuruluşları Radio Free Europe (RFE - Özgür Avrupa Radyosu) ve Radio Liberty'nin (RL - Özgürlük Radyosu) oluşumuna ait izler 1947-1948'e değin takip edilebilir. Söz konusu konjonktür; Doğu Avrupa üzerinde Sovyet hâkimiyetinin belirdiği, Batı Almanya'ya yönelik bir lojistik desteği olarak Berlin hava köprüsünün (Berlin airlift) tesis edildiği, Marshall Planı'nın hayat bulduğu, Demir Perde'nin şekillendiği; nihayetinde Doğu, Orta ve Batı Avrupa'nın fiziksel olarak bölündüğü dönemlerdir (Cummings, 2009, 5-6). İşte böyle bir sosyo-politik atmosferde dönemin ABD hükümeti, Merkezi ve Doğu Avrupa ile Sovyetler Birliği'ne yönelik yayın yapan Radio Free Europe ile Radio Liberty'i 1950’lerin başlarından itibaren desteklemeye başlamıştır. Bunlardan ilki, başlangıçta o dönem Polonya, Çekoslavakya, Macaristan, Arnavutluk, Romanya ve Bulgaristan'a yayınlarını yöneltmiştir. İkincisi ise 1953'te Sovyetler Birliği'ne yayın faaliyetine başlamıștır. Bunlar, özel bir ABD şirketi tarafından yürütülen teknik bağımsız hizmetler olmakla birlikte, her iki uluslararası radyo da Amerikan Dışişleri Bakanlığı tarafından tasarlanmış ve Amerikan Merkezi İstihbarat Teşkilatı'ndan (CIA) önemli miktarda fon alarak yola koyulmuşlardır (Weed, 2016, 2).

Bu bağlamda, Radio Free Europe, Doğu Avrupa'daki özgürlüğü arzulayan halklar üzerinde Sovyetlerin militarist boyunduruğunu kırmak ve etkisiz kılmak amacıyla görünüşte "objektif" haber ve bilgi sağlayarak söz konusu kesimleri motive etmeye çalışırken; Radio Liberty ise sadece Rus dinleyicilere hitap edecek bir yayın politikasına girișmiştir. Daha sonraki süreçte; Sovyetler'in istihbarat ve gizli servisi KGB tarafindan Radio Liberty, Voice of America, BBC Dünya Servisi ve Alman Deutsche Welle'nin topluca "Sesler - The Voices" olarak isimlendirildiği ortaya çıkmıştır (Taylor, 2003, 261-262).

Doğu Avrupa ülkelerinin komünizmin kontrol ve etki alanına girmesinin yanı sıra 1940'ların sonlarında Sovyetlerin saldırgan propagandası, Birleşik Devletlerin psikolojik operasyonlar, politik savaş ve uluslararası yayıncılığı içerecek şekilde yabancı enformasyon programlarını desteklemesi konusunda bir katalizör işlevi görmüştür. Daha da ötesinde 1969 tarihli gizli bir CIA raporunda Radio Free Europe ve Radio Liberty, Sovyetler Birliği ve Doğru Avrupa'nın hedeflendiği “en eski, en geniş, en maliyetli ve muhtemelen en başarılı gizli eylem projeleri” olarak nitelendirilmiştir 
(Cummings, 2009, 5). Dolayısıyla Soğuk Savaş ile propaganda aracılığıyla mücadele etmek, hükümet çevrelerinde uluslararası yayıncılığın en önemli işlevlerinden biri olarak değerlendirilmiştir (Rawnsley, 1999, 178).

Uluslararası yayıncılığın tarihsel serüveninde yurt dışı hedef kitlelere yönelik yayınlar, Soğuk Savaş dönemi de dahil olmak üzere uzunca bir süre ağırlıklı olarak radyo aracılığıyla devam etmiştir. Bu anlamda radyo, uluslararası yayıncılığın söz konusu dönemlerinde ana aktörü ve iletişim mecrası olmuştur. Ancak iletişim teknolojileri geliştikçe değişen ve dönüşen iletişim ortamı, medya ve iletişim alanında her sektörü şekillendirme sürecine tabi tuttuğu gibi uluslararası yayıncılık alanına da biçim vermiştir.

Bu bağlamda dünyada 1960'lı yıllarda altın çağını yaşamaya başlayan televizyon, teknik anlamda gelişme kaydederek iletişim ortamına damgasını vurmaya devam ederken; 1990'lardan bu yana dijitalleşme ve uydu yayıncılığın yaygınlaşması gibi yenilikler, dünyanın çeșitli yerlerindeki yayın istasyonlarının, radyodan televizyona doğru hızlı bir biçimde evrilmesiyle sonuçlanmıştır. Bu dönüşüm, uluslararası yayıncılık kapsamında bilginin dolaşıma sokulması sürecinde daha güçlü bir kitle iletişim aracı olarak, odağın radyodan televizyona kayması sonucunu doğurmuştur. Öyle ki; uluslararası yayıncı aktörler, sadece Batı'da değil, Doğu Asya'da da hızla değişen dünya ölçeğindeki uluslararası yayın alanının önlerine çıkardığı zorlukların üstesinden gelme noktasında bir çaba içine girmişlerdir (Norihiro, 2009, 21).

Uluslararası iletişim alanında uzunca bir süre Batı'nın kendi değer, çıkar ve bakış açılarına dayalı hegemonik bir küresel haber ağı hâkim olmakla birlikte; görece daha yakın dönemlerde uluslararası yayıncılık ve iletişim alanı, diğer ülkeler tarafından bölgesel ve küresel ölçekteki televizyonların finanse edilmesi ve geliștirilmesi süreciyle farklı bir görünüm kazanmaya bașlamıștır. Bu kapsamda, dünya ölçeğinde yerel ve bölgesel hizmetler sunan çok sayıda uydu haber kanalının yanı sıra uluslararası yayıncılık sahasında Rusya'dan Russia Today (RT), Katar'dan Al Jazeera (El Cezire), Çin'den Çin Merkez Televizyonu (CCTV) ile France 24 ve Deutsche Welle gibi ikinci kademe Batı uluslararası televizyon kanalı türünde küresel aktörler ortaya çıkmış ve bunlar birçok dilde yayıncılık faaliyeti gerçekleştirmeye başlamıştır. Bu uluslararası yayıncı aktörler, kendi kanallarındaki yayın faaliyetine ek olarak kimi zaman da diğer kanallarda veya yerel yayıncı kuruluşlara günlük ya da haftalık programlar hazırlayabilmektedir. Televizyonla ve giderek çeşitlenen iletişim ortamıla birlikte bu yeni aktörler dizisi, özellikle gelişmekte olan ülkeler için uluslararası yayıncılık alanında yayın ve tercih noktasında geniş bir yelpaze sunmaktadır. Bu yayıncı kuruluşlar, ayrıca Kuzey Amerika ve Avrupa'daki izleyicilere de ulaşabilmektedir (Aktaran: Si, 2014, 2).

Bu gelişim trendi içinde Türkiye'ye bakıldığında; TRT’nin uluslararası yayıncılık alanındaki televizyon yayınlarının ilk etapta TV 5 INT adıyla 1990 yılında başladığı ve daha sonra bu kanalın TRT INT adını aldığı görülmektedir. Söz konusu yayınların hedef kitlesi ise öncelikle Almanya olmak üzere, çalışmak amacıyla Avrupa'ya yerleşmiş olan Türkler olarak belirlenmiştir. Uluslararası yayıncılık alanındaki bir diğer aktör ise TRT-INT Avrasya adıyla 1992 yılında yayın hayatına başlamıştır. Bugün TRT Türk adıyla yayın faaliyetini sürdüren bu kanal, o dönemde 1991 yılında Sovyetler'in dağılması ile ortaya çıkan siyasi tabloda bağımsızlığını kazanan Türki Cumhuriyetlere yayın yapmak amacıyla kurulmuştur (Demirkıran, 2008, 257-258). 
Türkiye'nin uluslararası yayıncılık paradigmasındaki dönüşümün temel yansıması olarak kabul edilebilen TRT World ise ilk etapta 2015 yılının Mayıs ayından itibaren şifreli olarak yayınlara başlamıştır ve aynı yılın Kasım ayından bugüne şifresiz olarak yayınlarını sürdürmektedir (Devran, 2015, 289-290).

Televizyondan sonra 1960’lı yıllardan itibaren başlayarak günümüze kadar aşama aşama gelişme kaydeden, yeni bir elektronik ve kültürel mekânın kapılarını aralayan internet ve 21. yüzyılın başlarından itibaren sosyal medya, uluslararası yayıncılığı yeni mecralara taşımıştır. Bu bağlamda, uluslararası yayıncı kuruluşlar, hem kendilerine geniş bir kontrol ve yönetim imkânı sunan web sayfaları üzerinden yayın yapmaya başlamış hem de kullanıcılara da üretim ve katılım imkânı sunan Facebook, Twitter, Instagram, YouTube gibi ana sosyal medya platformları ve diğer ağlarda yer almışlardır. Bu yeni mecralar, uluslararası yayıncılık bağlamında bir taraftan geleneksel iletişim ortamlarında zaten bu yayıncılık faaliyetini icra eden aktörlerin faaliyet alanına çeşitlilik-etkileşim-bütünlük kazandırırken; diğer taraftan da uluslararası yayıncılık alanındaki potansiyel hegemonik alanın daha fazla kırılması noktasında kayda değer olanakları hem bu aktörlerin hem de kullanıcıların önüne sermektedir. Öte yandan, uluslararası yayıncılığın başlangıcında ön plana çıkan propaganda yoğunluklu faaliyetlerin, söz konusu mecralar aracılığıyla hitap ettiği hedef kitleleri her yönden sarıp sarmalaması tehlikesi de önemli bir komplikasyon ihtimali olarak masada durmaktadır.

\section{Uluslararası Yayıncıı̆̆ın Kodları: İlkelerden Değerlere İşlevler Skalası}

Uluslararası yayıncılık, iletişim literatürü içinde uluslararası iletişimin çatısı altında yer alsa da ilk etapta akla gelen uluslararası haber ajansları, çokuluslu şirketlerin medya ve iletişim alanında mülkiyet ve sahiplik yapıları, küreselleşme ve iletişim gibi konuları öncelikli olarak imlememektedir. Bu kapsam, uluslararası yayıncılık içinde yer almakla birlikte kavramın ana çerçevesini bir başka gönderim noktası oluşturmaktadır. Genel bir çerçeveden bakıldığında; uluslararası yayıncılık, iletişim teknolojilerine koşut olarak zamanın ve mekânın sıkışmasını ve toplumsal ilişkilerin yeniden bileşimini içerecek şekilde dünya ölçeğindeki güç ve iletişim ilişkilerinin gerilim hattı boyunca sürdürülen bir yayıncılık türü olarak düşünebilir (Atewolara-Odule ve diğerleri, 2016, 16). Bu hat; uluslararası ilişkilerin, politikaların ve mücadelelerin bir uzantısı ve yansıması olarak işlevsellik kazanan iletişim ortam ve teknolojilerinden oluşan bir mecralar dizisinde hayat bulmaktadır.

Uluslararası yayıncılık kavramı; devlet destekli haber, enformasyon ve eğlence içerikli mesajların bu yayıncılık faaliyetini destekleyen devletin sınırları dışındaki bir nüfusa yönlendirilmesi olarak tanımlanabilir (Price, 2003, 53). Buna göre; uluslararası yayıncı kuruluşlar, hem içinde bulunduğu ülkenin dışındaki izleyicileri bilgilendiren hem de sponsor ülkelerin imaj ve itibarını iyi niyetle tanıtan, gazetecilik ve enformasyona dayalı devlet destekli haber medyasını kapsamaktadır (Powers ve Youmans, 2012, 3). Uluslararası yayıncılık faaliyetinin içerdiği devlet desteği, her zaman için belirgin ve açlk bir görünüme sahip olmayabilir. Örneğin, uluslararası yayıncılık kavramının buradaki tanımıyla CNN tam olarak bu kategoride yer almamakla birlikte, Amerikan hegemonyasının bir enstrümanı olarak işlev gördüğüne yönelik süreğen bir tartışmanın odağında yer almaktadır. Benzer şekilde, kendi bölgesel politik ortamına ilişkin ön kabuller taşıyan bir yayıncı olduğu tartışılmakla birlikte El Cezire televizyonu, uluslararası 
yayıncılığın içerdiği biçimde devlet tarafından desteklenme veya finanse edilme özelliğini tam olarak taşımamaktadır (Price, 2003, 53).

Uluslararası yayıncılıkta bilinçli bir biçimde içinde bulunulan ülke dışındaki hedef kitleye ulaşmaya yönelik bir bilgi yayım süreci bulunmaktadır. Bu bilgi yayımı; uzun dalga, orta dalga, kısa dalga, doğrudan uydular aracılığıyla ve günümüzde internet ve sosyal ağlar üzerinden gerçekleştirilebilmektedir. Yayıncılığın bu formunu diğer yayıncılık türü ve kuruluşlarından ayıran temel niteliklerinden biri, hitap ettiği hedef kitlesidir. $\mathrm{Bu}$ hedef kitle ise temelde dış ülkelerde konumlanmış olan birey, grup veya topluluklardır (Ojomo, 2012, 44). Bir ülke tarafından başka ülkelere yönelik olarak tasarlanan yayınlar olarak da değerlendirilebilen uluslararası yayıncılık, hükümetler tarafından organize edilip desteklenebildiği gibi resmi dıș servisler ya da gayriresmî merkezler olarak kamu/özel kuruluşlar veya dini gruplar aracılığıyla da gerçekleştirilebilmektedir. Bu bağlamda, Radio Peking, Voice of America ve Deutsche Welle gibi uluslararası yayın kuruluşları, devlet destekli yayın kategorisine girerken; tarihsel süreçte dini misyon işleviyle yükümlenmiş Voice of the Andes, the Far East Broadcasting Corporation, Trans-World Radio ve Voice of the Gospel gibi örnekler de yine uluslararası yayıncılık kapsamındaki başlıca dini yayıncılar arasında yer almıștır (Ronalds, 1971, 72).

Bu bağlamda, uluslararası yayıncılığı motive eden ana motivasyonlar doğrultusunda yayıncı aktörlerin yerine getirdikleri işlevler de değișebilmektedir. Bir başka deyişle, bu yayıncılık sahasında faaliyette bulunan dini yayıncı kuruluşlar ile politik içeriği yoğun haber medyasının yerine getirdiği işlevler farklılaşmaktadır. Uluslararası yayıncılığın ne tür işlevleri bünyesinde barındırdığı konusu, aynı zamanda uluslararası yayıncılığın ilke ve kodları açısından da önemli ipuçları sunan bir alana işaret etmektedir. Öte yandan; uluslararası yayıncılığın etrafında örgütlendiği ilke, değer ve kodlar ile yerine getirdiği işlevlerin, normatif bir tanımlama mı olduğu yoksa gerçekliğe karşılık gelip gelmediği meselesi de hassas bir tartışma alanını içermektedir.

Zira, Douai'nin $(2009,17)$ vurguladığı üzere; ideolojik pozisyon ve coğrafi konuma bağlı olarak uluslararası yayıncılık girişimleri, değişik biçimlerde propaganda, medya diplomasisi ve daha genel olarak kamu diplomasisi gibi kavramlarla ilişkilendirilmektedir. Bir başka deyişle, bu tür motivasyonlar, uluslararası yayıncılığı teşvik ederken, bunlardan bir veya birkaçı ana motivasyon olarak ön plana çıkabilmektedir. Bu durum, uluslararası yayıncı kuruluşun ve arkasındaki örgütlü desteğin temel yönelimiyle doğru orantılı olarak hayat bulmaktadır.

Tarihsel gelişim sürecinin başlangıcında dünya savaşında ve Soğuk Savaş döneminde uluslararası yayıncılık ağırlıklı olarak propaganda işleviyle karakterize olmuştur. Örneğin; Rawnsley $(1996,8)$ Soğuk Savaş süresince propagandanın yayılması noktasında en büyük katkıyı sağlayan aktörün uluslararası radyo yayıncılığı olduğunu ifade etmektedir. Risso $(2013,147)$ ise söz konusu dönemde radyo propagandasının "kültürel Soğuk Savaş"ın önemi ve karakteriyle ilgili daha geniş bir tartışmanın parçası olduğuna işaret etmekte ve silahlanma yarışının yaptığı gibi, Soğuk Savaş’ın "kalplerin ve zihinlerin kazanılması"yla da ilgisi olduğunun yaygın olarak kabul edildiğine dikkati çekmektedir.

1990’lardan bu yana baktığımızda ise dönüșen sosyo-politik konjonktür ve yeni iletişim teknolojilerindeki gelişmelerle birlikte uluslararası yayıncılık da ilk 
dönemlerinden görece farklı bir evreye taşınmıştır. Bu farklılık ise daha önce propaganda ile yoğrulan işlevlerin görece farklılaşmasını ve daha rafine formlara bürünmesini beraberinde getirmiștir. Uluslararası yayıncılığın günümüz dünyasında yerli yerinde anlamlandırabilmesi için kamu diplomasisi kavramının çağrışımlarına da bakmak gerekmektedir.

Kamu diplomasisi, dış politikanın inşasında ve icrasında farklı ülkelerdeki kamu tutumlarının etkisi üzerine yoğunlaşan bir anlam yelpazesine işaret etmektedir. $\mathrm{Bu}$ bağlamda geleneksel diplomasiden farklılaşan kamu diplomasisi, uluslararası ilişkilerin farklı boyutlarını içermektedir. Buna göre, kamu diplomasisi; hükümetler tarafından diğer ülkelerdeki kamuoyunun hazırlanması, bir ülkenin başka ülkelerdeki özel gruplar ve onların çıkarları ile etkileşim içine girmesi, dış meselelerin ve onların politika üzerindeki etkisinin raporlanması ve diplomatlar, yabancı gazeteciler gibi işi iletişimle ilgili olanlar arasındaki iletişimi ve kültürlerarası iletişim süreçlerini kapsamaktadır (http,//fletcher.tufts.edu, Erişim: 01 Eylül 2015). Kamu diplomasisinin ögelerini sınıflandıran Cull (2008, 31-32) da dinleme, savunma, kültürel diplomasi ve değişim diplomasisinin ardından beşinci öge olarak uluslararası yayıncılığa işaret etmektedir.

Kamu diplomasisi ve uluslararası yayıncılığın kesişmesinin tarihsel arka planına bakıldığında; öncelikle Soğuk Savaş sonrası dönemden itibaren başlayan jeopolitik dönüşüm, yeni teknolojiler, büyük tecimsel medya kuruluşlarının yükselişi, hükümetlerin ve toplumun bu yayıncılık türüne yönelik desteğinin görece zayıflaması gibi bir dizi gelişmenin, uluslararası yayıncı aktörlerin misyonları üzerine yeniden düşünülmesi sürecini tetiklediği görülmektedir (Price, 2003, 58-60)

Daha özelde ise 11 Eylül 2001 terör saldırısı ve sonrasındaki Irak savaşı, kamu diplomasisi ve uluslararası yayıncılığın geleceğiyle ilgili tartışmalara güncellik kazandırmıştır. Söz konusu tartışmalar, bir toplumun çıkar anlayışının diğer toplumların medya ortamıyla bağlantılı olduğu düşüncesini öncelemeye başlamıştır. Bu tartışma, aynı zamanda hedef topluma yönelik yayınların karışımını değiştirmek, hedef toplumlarda daha büyük sivil katılımı sağlamak ve nihayetinde kalpleri ve zihinleri kazanmak için ulusal hedeflerin tartışılmasının işin içine girdiği başka bağlamları da içermiştir. Dolayısıyla, bu süreçte kamu diplomasisine yönelik bir devrim, uluslararası yayıncılığın uygulanması için de kritik bir alan olarak belirmiştir. Bu değerlendirmeleri yapan Price (2003, 84), uluslararası yayıncı kuruluşların, tecimsel yayın kuruluşlarını taklit etmeye başlayarak haber ve eğlence içeriklerden "nesnel ve tarafsız" röportajlara kadar belirli bir kültürün ya da üslubun tanıtılmasına yönelik bir yayın açılımı olabileceğini öngörmüştür. Bu süreçte yeni teknolojiler, yeni türler ve yeni ortaklık biçimleri gibi faktörlerin uluslararası yayıncılığın geleceğine yön vereceği ifade edilmektedir.

Bu bağlamda; uluslararası yayıncılık, birçok ülkenin kamu diplomasisi çabaları içinde önemli bir dayanak noktası olarak işlevsellik kazanırken, devletlerin bu uluslararası yayıncı aktörlere atfettiği işlevler farklılaşabilmektedir. Buna göre; İngiltere, Amerika, Fransa, Hollanda ve Almanya'nın uluslararası yayıncılık deneyiminin karşılaștırmalı analizi doğrultusuna olası altı işlev belirginlik kazanmaktadır. Çoğu Batı uluslararası yayın kuruluşunun iki temel işlevi vardır. Bunlardan ilki, kriz anlarında doğru bilginin temini için bir ağ olarak işlev görmektir. Diğer temel işlev ise azgelişmiş bölgelerde medyanın arz eksikliğini 
telafi edebilmektir. Öte yandan, Fransa ve Almanya'nın özellikle iki işlev üzerine odaklandığı öne sürülebilir. Bu işlevler; belli bir kültürün ve dilin temsili ile yurt dışındaki yurttaşlar için anavatana bir bağlantı imkânı sunulmasıdır. Bu tablo içinde Amerikan yaklaşımını karakterize eden en temel işlev de "belirli sosyal ve politik inançları, kavrayış ve ideolojileri yayma hedefine sahip bir misyoner niteliği" taşımasıdır. Son olarak, BBC örneğine bakıldığında ise küresel bir haber kanalı olmanın yanı sıra misyonerlik işlevi de dâhil olmak üzere tüm diğer işlevleri kapsamaya çalışan küresel bir aktör olma çabasından söz edilebilir (Richter, 2008, 1-2).

Uluslararası yayıncı kuruluşların işlevlerine yönelik bu analitik sınıflandırma, bir taraftan hem farklı kültürler arasında hem de bir ülkenin başka coğrafyalardaki 'kültürel' yurttaşlarıyla bir diyalog potansiyeline işaret ederken; diğer taraftan da özellikle ABD ve İngiltere örneğinde uluslararası yayıncı kuruluşların bir misyon üstlenme vazifesine de gönderme yapmaktadır. Bu misyon üstlenme işlevi kendi içinde, yayıncı kuruluşun yer aldığı ülkenin politik, ekonomik, dini ve kültürel değerlerini idealize eden ve uluslararası yayıncılığın ilk dönemlerinde öne çıkan işlevlerine yönelik çağrışımlar taşıyan bir anlam yelpazesine sahiptir.

O’Keeffe ve Oliver da $(2010,14)$ kamu diplomasisindeki hedeflerine ulaşabilmek amacıyla hükümetleri uluslararası yayıncılığı kullanmaya motive eden beş temel faktörden söz etmektedirler:

\footnotetext{
“1. Özellikle eski sömürgeler gibi enformasyon açığının olduğu yerlerde enformasyon ve fikirler için alternatif güvenilir kaynaklar sağlamak.

2. Diasporalara erişebilmek.

3. İngilizce olmayan dilleri muhafaza etmek.

4. Batı'nın ve İngilizcenin medyatik, kültürel ve politik egemenliğine karşı koymak.

5. Bir ülkenin kültürünü, ideallerini, değerlerini ve uzmanlığını yansıtmak."
}

Codding de (1959, 65) UNESCO için 1959 gibi erken bir tarihte hazırladığ "Broadcasting without Barriers" başlıklı çalışmada ülkeler arasında uluslararası yayıncılığın ideal hedeflerine ilişkin bir fikir birliği olduğunu belirtmektedir. Buna göre uluslararası yayıncılığın ilk işlevi, yayın yapan veya destekleyen ülkenin kültür ve fikirlerini en iyi biçimde temsil etmektir. Diğer işlevler ise dünyaya ilişkin gelişmeleri objektif biçimde sunmak, yayını destekleyen ülkenin önemli dünya sorunlarına yönelik bakış açısını paylaşmak ve uluslararası anlayışı geliştirmek olarak sıralanmaktadır.

$\mathrm{Bu}$ türden işlevlerin, uluslararası yayıncılığın değerlerine ve kodlarına yönelik görece olumlu bir imayı ve iyi niyeti taşıdığı öne sürülebilir. Örneğin, dünyaya ilişkin gelişmeleri objektif biçimde sunmak ve ilgili ülkenin dünya sorunlarına ilişkin bakış açısını yansıtmak arasında ilkesel bir fark belirmektedir. İlkinde tecimsel yayıncılık sürecinde de bir ideal olarak var olmakla birlikte çoğu zaman gözetilemeyen veya uygulama aşındırılan bir nesnellik idealine işaret edilmektedir. Diğer işlev ise uluslararası yayınlarda bir ülkenin bakış açısının mutlak doğru gibi sunulmaksızın sunumu şeklinde gerçekleşmesi hâlinde görece açık ve şeffaf bir habercilik pratiği olarak düşünülebilir ve bu anlamda uluslararası yayıncılığın kamu diplomasisinde kullanımı hanesine yazılabilir.

Öte yandan, işlevlere ilişkin bu tarz sınıflandırmaların yanında başarılı bir uluslararası yayıncılık göstergesi için önkoşul, diğer yayıncılık türlerinde olduğu 
gibi güvenilirliktir. Bu güvenilirlik, ticari medyanın mülkiyet ve sahiplik yapısı tartışmalarındakine benzer biçimde herhangi bir yayıncının kendini finanse eden hükümetlerden tam bir editoryal bağımsızlık içinde çalışmasıyla elde edilebilmektedir. Bu bağlamda, tıpkı İngiltere, Hollanda, Almanya, Japonya ve birkaç başka örnekte olduğu gibi bağımsızlığın en etkin garantisi, yasal koruma olarak kabul edilebilir. Burada bir dipnot olarak, yasal korumanın da aşındırılmaya açık alanları olduğu notu düşülebilir. Öte yandan, Çin Merkez Televizyonu (CCTV) gibi bir başka örnekte; bunun Çin hükümetinin bir propaganda aracı olarak algılanması ise kendi vatandaşları üzerinde olmasa bile özellikle uluslararası ölçekte güvenilirliğini ve seyirci sadakatini tehlikeye atan belirgin bir referans noktasıdır. Güvenilirliğin önemli bir referansı olarak kabul edilen editoryal bağımsızlık dışında uluslararası yayıncılığın başarılı bir grafik çizebilmesi için başka faktörler de sıralanabilir. Bu kapsamda, özellikle istikrarlı bir finansman çevresi, yayınlarda tutarlılık ve uzun ömürlülük başı çeken faktörlerdir. Diğer taraftan, ülkenin dış politika hedefleriyle uyumlu bir perspektifi temsil sürecine yansıtabilmek amacıyla uluslararası yayıncı aktörlerin stratejik yönelimlerinin dışişleri bakanlıklarıyla iş birliği ilişkisi içinde yürütülmesi de bir başka önemli noktadır. Bu son kriter, uluslararası yayıncılıkta yukarıda söz edilen editoryal yönelimin tersine bir işleyișe gönderme yapmaktadır (O'Keeffe ve Oliver, 2010, IV-V). Şöyle ki editoryal bağımsızlık; nesnel ve dengeli bir haber sunumu ve akışını gerektirirken; ülkenin dış politika hedefleriyle uyum, dengelilik açısından bir pay taşıyabilse bile nesnellik boyutunu oldukça kırılgan hâle getirmektedir. Bir başka deyişle, dıș politikaya doğrudan ve katıksız bir angajman, haber sunumu ve akışında nesnellik ilkesini her zaman için köşeye sıkıştırmaya mahkûmdur.

Kamu diplomasisi bağlamında düşünüldüğünde; uluslararası yayıncılığın teknolojik gereksinimleri, onu diğer kamu diplomasisi unsurlarından ayrıştıran bir nokta olarak ön plana çıkmaktadır. Öte yandan, uluslararası yayıncılığın kamu diplomasisi kapsamında ele alınması ve onunla bir kesișim hattına sahip olması, uluslararası yayıncılığın etik temelini oluşturma potansiyelini taşıyan anahtar bir unsurdan kaynaklanmaktadır. $\mathrm{Bu}$ unsur, gazeteciliğin de temel hammaddesini teşkil eden haberdir. Tarihsel olarak bakıldığında; uluslararası yayıncılığın en güçlü ve etkili unsuru, özellikle objektif kullanımı söz konusu olduğunda haber olmuştur. Bir başka deyişle, propaganda yönelimli haberler, ilgili dönemde bir etki oluştursa dahi uluslararası yayıncılığın olumsuzluk hanesine yazılırken; objektif haber sunumunun uluslararası yayıncılığın kredibilitesini yükselttiği söylenebilir. Bu potansiyel, bir ülkenin kendi gazetecilik ve iletişim alanındaki tarihsel deneyimi içinde oluşan etik kültürüyle de bağlantılı olarak uluslararası yayıncılığı etkilemektedir. Bu denklem içinde hükümet veya devletlere yönelik belli bir mesafeli tutumun var olduğuna yönelik gerçek zeminli bir kamuoyu algısı, uluslararası yayıncılık içinde böyle bir habercilik pratiğinin kanıtı olarak olumlu katkı sağlamaktadır (Cull, 2008, 31-32).

Bu tartışma ekseninde; uluslararası yayıncılıkla ilgili temel standartların ve ilkelerin neler olduğuna uluslararası yayıncı aktörlerin kendi tanımlamaları üzerinden bakmak, önemli bir rezerv niteliği taşımaktadır.

Örneğin, Voice of America'nın internet sitesinde uluslararası yayıncılık kapsamında gözetilen birtakım standartlara işaret edilmektedir. Buna göre; öncelikle söz konusu yayıncı kuruluşun tutarlı bir şekilde güvenilir ve saygın bir haber kaynağı olarak görev yaptığı ifade edilmektedir. Bir başka kriter de haberlerin doğru, tarafsız ve 
kapsamlı olması gerekliliğidir. Söz konusu standartlardan bir diğeri; Amerika'nın Sesi'nin yalnızca Amerikan toplumunun bir bölümünü değil, tüm Amerika'yı temsil ettiği ve Amerikan düşünce yapısı ile kurumlarını dengeli ve kapsamlı bir şekilde yansıtmakla yükümlü olduğu vurgulanmaktadır. Son olarak ise Voice of Amerika'nın Amerikan yönetiminin politikalarını açıkça ve etkili bir şekilde yansıttığı ve bu politikalar konusunda sorumlu tartışmaları ve görüşleri yayınladığı belirtilmektedir (http://www.amerikaninsesi.com, Erişim: 05.09.2015). Bu işlev skalasında ilk etapta güvenilirlik algısının tutarlı biçimde sürdürülmesine referans verilmektedir. İkinci kriter, genel gazetecilik kodlarıyla örtüşen bir tanımlama olarak dikkati çekmektedir. Üçüncü standart, uluslararası yayıncı kuruluşun temsil işlevini bütün bir topluma yaymaktadır. Üçüncü işlevin bir kısmı ile dördüncü yükümlülüğün ise bir taraftan diplomasi ve kamu diplomasisi ile örtüşen bir bağlama gönderme yaparken; diğer taraftan da propagandanın çağrışımlarını taşıdığı ifade edilebilir.

Bir başka örnek olarak; Radio Free Europe/Radio Liberty'nin internet sitesine bakıldığında da söz konusu uluslararası yayıncı kuruluşların birtakım misyonları benzer şekilde sıralanmaktadır. Buna göre; bu yayıncı kuruluşun ilk misyonu, başarılı bir demokratik ve serbest piyasa dönüşümü için kritik yerel ve bölgesel sorunlara ilişkin objektif haber, analizler ve tartışma sağlamak şeklinde formüle edilmektedir. İkinci sırada, demokratik değerlerin yansıtılması suretiyle sivil toplumun güçlendirilmesi gelmekte ve hemen ardından etnik ve dini hoşgörüsüzlük ile mücadelenin ve halklar arasında karşılıklı anlayışın teşvik edilmesine işaret edilmektedir. Yine, bu yayıncı kuruluşun yerel medya kuruluşlarıyla ortaklıklar geliştirilmesi, bağımsızlığı ve medya profesyonelliğini desteklemek amacıyla yerel medyaya bir model sunması gerekliği üzerinde durulmaktadır. Son olarak ise Radio Free Europe/Radio Liberty'e bölge ülkeleri ve dünyanın yerleşik demokrasi anlayışı arasında daha yakın ilişkileri teşvik etmesi yönünde bir misyon biçilmektedir. (http://www.rferl.org, Erişim: 05.09.2015).

$\mathrm{Bu}$ uluslararası yayıncı kuruluşun (RFE/RL) kendisine yönelik olarak tanımladı̆̆ı ilk işleve bakıldığında; demokrasi ve serbest piyasaya yönelik belli bir anlayış ya da modelin veri alındığına yönelik bir söylemin arka planda yer aldığı söylenebilir. İkinci ve üçüncü işlev, sivil toplumcu bir bakış açısını taşımakta ve çatışmanın diyaloğa dönüștürülmesi sürecinde uluslararası yayıncılığın üstlenebileceği pozitif bir potansiyele gönderme yapmaktadır. Yerel medya kuruluşlarıyla ortaklık geliştirilmesi ve onlara yönelik model oluşturma girişimi ise iki açıdan irdelenebilir. Bir yönüyle bu misyon, medyanın yerel aktörlerini desteklemeye, teşvik etmeye ve geliştirmeye yönelik bir imayı barındırmaktadır. Diğer yanıyla ise gazetecilikte mesleki profesyonellik ideolojisinin transferinin, aynı zamanda iş yapma biçimleri ve kültürü ile mesleki kodların transferini de beraberinde getirdiğine yönelik görece eleştirel bir değerlendirme de bulunmaktadır. Bu durum, gazetecilik gibi kamusal bir bilgi verme ve yayım ortamının, hedef ülke veya ülkelerin böylesine stratejik bir mesleki bağlamda kültürlenmesi olarak da okunabilir. Söz konusu uluslararası yayıncı kuruluşlara yönelik belirtilen son işlev ise yine demokrasinin tesisi ve yaygınlaştırılması ekseninde diyalog ve ilișki geliștirilmesine gönderme yapmaktadır.

Daha genel olarak, Birleşik Devletler Uluslararası Yayıncılık Kanunu'na bakıldığında, standartlar ve ilkeler başlığı altında; uluslararası yayıncılıkta Amerika'nın geniş dış politika hedefleri ve uluslararası telekomünikasyon politikaları ile tutarlılık, gazeteciliğin en yüksek standartlarla uyumlu biçimde yürütülmesi, haberlerde 
güvenilirlik, doğruluk, tutarlılık ve objektiflik, potansiyel izleyiciler hakkında güvenilir enformasyona sahip olunması, dünyanın her bölgesindeki önemli gelişmeler hakkında bilgi verilmesi ve din özgürlüğü de dâhil olmak üzere insan haklarına saygının teşvik edilmesi gibi benzer birtakım kriterler sıralanmaktadır (http://www.bbg.gov, Erişim: 05 Eylül 2015).

Uluslararası yayıncılık kapsamında Türkiye'deki uluslararası televizyon yayıncısı aktör olan TRT World'ün internet sitesine bakıldığında ise yayıncı kuruluşun misyonu; olumlu davranış kalıplarını etkilemek, tartışmayı teşvik etmek, yerleşik varsayımlara meydan okumak ve anlayış zeminini genişletmek şeklinde formüle edilmektedir. Bu formülde, TRT World dünyada pozitif yönde bir değişimin itici gücü olarak konumlandırılmaktadır. TRT World, yayıncılığı çerçevesinde hedef kitlesinden düşünce kalıplarında bir değişimi, sosyal sorunlara ilişkin farklı bir bakış açısını ve farklı kültürler ile etnisiteleri daha derinlikli biçimde anlamayı içeren bir reaksiyon almayı hedeflediğini belirtmektedir. Bu doğrultuda da hedef kitlesini, haber hikâyelerinin merkezinde olmayı hak eden, küresel bir vicdan ve inançla donanmış küresel vatandaşlar olarak tanımlamaktadır (https://www.trtworld. com, Erişim: 15.10.2018). Burada TRT World'ün işlevselliği bağlamında özellikle siyasal, ekonomik, toplumsal ve kültürel konularda farklı bakış açllarını yansıtan bir habercilik pratiğine vurgu yapıldığı görülmektedir. TRT World'ün misyonunun ise dünya ölçeğinde kültürlerarası diyaloğu ve anlayışı geliştirmeyi imleyerek, uluslararası yayıncılığın bir ideal olarak öne çıkan diyalojik karakterine vurgular taşıdığı söylenebilir.

Uluslararası yayıncı kuruluş örneklerinde görüldüğü üzere; prensipte ve normatif düzeydeki bu tarz ilkelerin uluslararası yayıncılığın icrasında ne düzeyde işlerlik kazandığı noktası, esas sorunsalı teşkil etmektedir. Örneğin, Alman uluslararası yayıncı kuruluşu Deutsche Welle TV Arabia kanalının Arap dünyasında medya destekli bir kültürlerarası diyalogu teșvik edip etmediğinin incelendiği bir çalışmada söz konusu kuruluşun içerikleri Al Jazeera ve al-Arabiya televizyonları ile karşılaştırmalı olarak analiz edilmiştir. Çalışmanın sonucunda Deutsche Welle'nin, diyalog kavramının içini; daha çok tek taraflı, kendine hizmet eden bir tarzda ve işlevselci bir strateji gibi doldurduğu değerlendirmesi yapılmaktadır. Bu doğrultuda Deutsche Welle TV Arabia'nın haber yayınlarına yönelik içerik analizi sonuçlarına bakıldığında; bu içeriklerin, ne hâkim Arap haber gündemine tam olarak uyum sağlayabildiği ne de bağlantılı konuların kullanımı suretiyle bu gündemle anlamlı bir şekilde ilişkilendiği ortaya çıkmaktadır. Bu bağlamda, eksik noktalar olarak ise; özellikle Ortadoğu'ya ilişkin bölgesel referans eksikliği, konuların yetersiz sunumu ve en çok çatışma odaklı haber gündemi şeklinde sıralanmaktadır. Öte yandan, Deutsche Welle'nin programları sanat, kültür, toplum ve ekonomi gibi alanlarda siyasi olmayan haberlere odaklanarak potansiyel bir kültürlerarası diyalog zeminine katkı sağlayabilir. Böylesi alanlara odaklanan bu tarz konular, çatışmalı politik meselelere göre kültürler arasında daha iyi bir diyalog üretilmesi potansiyeline sahiptir (Ricthter, 2008: 9-10).

Konuyla bağlantılı bir başka çalışmada ise Amerikan uluslararası yayıncılığının iki temel kuruluşu olan Voice of America (VOA) ve Radio Free Europe/Radio Liberty'nin (RFE/RL) Azerbaycan ve İran'daki yayıncılık faaliyetleri incelenmiş ve bu yayıncı kuruluşlar açısından demokrasinin teşvik edilmesinin stratejik bir öncelik olup olmadığı analiz edilmeye çalışılmıştır. Söz konusu yayıncı kuruluşların İran’la 
ilgili içeriklerinin analizine dayalı sonuçlara bakıldığında; Radio Free Europe/ Radio Liberty'nin demokrasi temalı hikâyelere öncelik verilmesi açısından Voice of America'dan daha önde olduğu bulgusuna ulaşılmıştır. VOA ise İran'ın nükleer emellerini konu edinen hikâyelere daha çok yer vermeyi tercih etmektedir. Dolayısıyla, VOA'nın içinde bulunulan dönemde özellikle Bush yönetimiyle bağlantılı Amerika'nın ajandasında üst sıralarda yer alan İran'ın nükleer emelleri türünden konulara daha fazla odaklandığı söylenebilir. $\mathrm{Bu}$ perspektiften bakıldığında; araștırmanın önemli bir sonucu da, RFE/RL'nin gündem belirleme sürecindeki inisiyatifinin aksine; VOA'nın kendi medya gündemini Amerikan yönetiminden gelen ipuçlarından hareketle oluşturduğu tespitidir. Buradan hareketle; RFE/RL'nin VOA'ya göre demokrasinin teşvik edilmesi ve zemin kazanması noktasında daha güçlü bir strateji izlediği söylenebilir (Brodsky, 2010, 285-286).

Uluslararası yayıncı kuruluşları için "verili bir perspektif ve çerçeveleme biçimleri" olduğunu söylemek mümkündür. Burada uluslararası yayıncı kuruluşların dikkat etmesi gereken belki en önemli nokta, gazetecilikteki "denge kuralı"nın dikkate alınmasıdır. Bir başka deyişle, haber konusu olay ya da sorunun tüm boyutlarıyla sunulması son derece önemli bir noktadır. Haber dışındaki diğer türden uluslararası yayınlarda ise hitap edilen toplumun dokusunun ve değer yargılarının dikkate alınarak programların hazırlanması da önemli bir gerekliliktir. Diğer taraftan, uluslararası yayıncılık bağlamında demokrasi ve insan haklarının salt kendi başına bir amaç olmak kaydıyla nirengi noktası olarak benimsenmesi de kayda değer bir referans oluşturmaktadır. Böylelikle, uluslararası yayıncılık, kültürlerarası diyalog gibi kritik bir misyonu çok daha fazla hayata geçirebilir.

Uluslararası yayıncılık literatüründe bu yayıncılığına atfedilen rollerin çeşitliliğinden hareketle; uluslararası yayıncılığın kod, ilke ve işlevler skalasını bir analojiden hareketle ele almak mümkündür. Bu skala, bir sarkacın işlemeye başladığı anda yaptığı salınım hareketi ve uğrak noktalarından hareketle açıklanabilir. $\mathrm{Bu}$ bağlamda; sarkacın harekete başladığı andaki ilk nokta, uluslararası yayıncılığın başlangıcındaki gibi ağırlıklı olarak propaganda ve endoktrinasyon yüklü işlevlerin durağı olarak düşünülebilir. Sarkacın salınım hareketinde ilk başladığı noktadan diğer uca vardığı andaki yeri ise gazeteciliğin etrafında örüldüğü bazı idealler olarak da nitelenebilecek nesnel habercilik, bilgilendirme, bağımsızlık, denge kuralı, kültürel geliştirme, motive etme gibi pozitif ilke ve işlevlerle çerçevelenmektedir. Sarkacın her iki uca eşit uzaklıkta olduğu tam orta nokta ise uluslararası yayıncılığın diplomasi, kamu diplomasisi ve yumuşak güç enstrümanı olarak işlev gördügü bir alan olarak tasavvur edilebilir.

$\mathrm{Bu}$ sarkaç analojisinde uluslararası yayıncılığın propaganda işlevinin öne çıktığı hareket noktası, uluslararası yayıncılığın tarihsel gelişim çizgisi içinde belli bir döneme kadar hâkim olan bir paradigmaya işaret etmekte ve birçok uluslararası yayıncl aktörün söz konusu dönemdeki faaliyetleriyle örneklendirilmektedir. Propaganda işlevinde öne çıkan ilkeler ise çoğunlukla tek taraflılık, öğreti ve değer aşılama ya da yayın yapılan ülke aleyhine hem o ülkedeki belirli kitleleri hem de farklı coğrafyalardaki kitleleri mobilize etmek şeklinde gerçekleşmektedir.

Sarkacın diğer ucunda yer alan ve pozitif olarak nitelenen işlev ise destek veren ülkenin dış politika hedeflerinin tümden reddedilmesi anlamına da gelmez. Burada önemli olan nokta; uluslararası yayıncılığa konu olan uluslararası, ulusal ve bölgesel 
sorunların insanı önceleyen bir bakış açısıyla insan hakları, uluslararası hukuk ve demokratik standartlar çerçevesinde sunulması olarak sıralanabilir. Burada; çok yönlülük, çok boyutluluk, dengelilik, bilgilendirme, doğruluk gibi motivasyonlar ön plana çıkar. Örneğin bu çerçeve ile örülü pozitif işlevlere yönelik bir sağlama, Suriyeli mültecilerin yaşadığı dram karşısında uluslararası yayıncı kuruluşların habercilik pratiklerine bakılarak yapılabilir.

Sarkacın ortasında ve civarında konumlanan işlevler ise kamu diplomasisi çerçevesinde uluslararası yayıncılığı, katıksız tek yönlü bir propaganda mecrası olarak değil de görece dengeli haber çerçeveleri üzerinden yumuşak bir güç olarak kullanma çabalarını içermektedir. Burada tutum değişimi, kültürel temas ve diyalog alanı olarak tasarlanan uluslararası yayıncılıkta ikna edici iletişim formlarının işlevsellik kazandığı söylenebilir. Ancak şunu belirtmek gerekir ki; sarkacın salınım hareketinde olduğu gibi bu işlevler skalası da kimi zaman açık kimi zaman örtük biçimlerde birbirinin alanına kolaylıkla kayabilmektedir. Diğer bir ifadeyle, uluslararası yayıncılığın bu sarkaç üzerinde açıklanan işlevleri kolaylıkla geçişkenlik kazanabilme potansiyeline sahiptir. Öyle ki, Irak savaşı örneğinde çokça tartışıldığı gibi; kimi politik aktörlerin söyleminde yer bulan "demokrasi promosyonu" söylemi, bazı uluslararası yayıncı kuruluşların da ana temsil çerçevesini oluşturabilmektedir.

\section{İnternet ve Sosyal Medya Çağında Uluslararası Yayıncılık: Değişim Alanları}

Son yirmi yılı aşkın bir süre zarfından beri dünya yapısal bir dönüşüm süreci içinden geçmektedir. Bu süreç, çok boyutlu ve çok aktörlü bir yapı sergilemekle birlikte; 1970'lerden itibaren şekillenen ve dünya ölçeğinde dengesiz bir şekilde yayılan bilgi ve iletişim teknolojilerine dayalı yeni teknoloji paradigmasının doğuşu ile bağlantılıdır (Castells, 2005, 3). Yeni iletişim teknolojileri özelinde 20. yüzyılın ikinci yarısından sonra gelişme aşamalarını kaydederek günümüze doğru yol alan internet ve 21. yüzyılın bu anlamdaki baş aktörü sayılabilecek sosyal medya; toplumsal, kültürel, ekonomik ve siyasal alanlarda olduğu gibi yayıncılık ve gazetecilik alanında da önemli değișim ve dönüşümleri tetiklemiștir. Bu ortam ve araçların bizatihi kendisi, kullanıcıların çok daha aktif ve üretken olabilmeleri yönünde imkân ve potansiyelleri beraberinde getirmiştir. İletișim alanında kișisel imkân yelpazesinin yanında grup, topluluk ve kurumsal imkân yelpazesi de benzer şekilde geniş bir ölçeğe sahiptir. Örneğin, sosyal medya platformları üzerinden grupların ya da sivil toplumsal hareketlerin kendi başlarına mobilize olabilme ve gündem oluşturma imkânı önceki dönemlerde hiç olmadığı kadar fazladır. Uluslararası yayıncı kuruluşlar ve tecimsel yayıncılık bağlamında düşünüldüğünde ise hem iletişim alanındaki hegemonik yapının sarsıldığı bir alanla hem de bu alana değişik şekillerde uyarlanma veya eklemlenme sorunuyla karşı karşıya kalındığı söylenebilir. Bu tablo, politik bağlamdaki uluslararası ve bölgesel çok aktörlü bir küresel dünyanın, teknolojik gelişmeler sayesinde atılım sağladığı iletişim ortamındaki karşılığı olarak da düşünülebilir.

İletișim ve kitle iletişimi bağlamında düşünüldügüne; dünya birbiriyle çok daha bağlantılı hâle gelmiş ve hakkında çok çeşitli ve alternatif kaynaklardan bilgi alınabilme potansiyeline sahip küresel bir köye doğru daha fazla evrilmiştir. Artık, bilginin tek ya da birkaç merkezden tek yönlü yayılımından ziyade; alandaki diğer aktörlerin, dominant ülkeler ve yayıncı kuruluşlarla enformasyonun biçimlenmesi ve yayılımı anlamında mücadeleye girebildiği merkezkaç bir yapı daha fazla mümkün hâle gelmiştir. Bir başka deyişle, özellikle internet ve sosyal medya 
özelinde habercilik, temsil ve yayıncılık gibi alanlarda gerek uluslararası gerekse ulusal aktörlerin söylem ve durum tanımları üzerindeki mücadelesi daha belirgin ve olanaklı bir yapıya bürünmüştür.

Uluslararası yayıncı kuruluşlar, oldukça uzun bir zaman dilimi boyunca önce kısa dalga radyo ve ardından 1980'lerin ortalarından sonra uydu televizyonları aracılığıyla faaliyetlerini gerçekleştirdikleri süreçte; haber ve bilgileri ulusal sınırların ötesine taşıyan kitle iletişimi alanındaki başat aktör olmuştur. İnternet ve sosyal medyanın araladığı yeni çağda ise gerçek zamanlı yayınlar ve dünyanın hemen her köşesinden bilgi ve yorumlar her an ve her yerden erișilebilir hâle gelmiștir. Öte yandan, bu dönemde haber toplama ve yayma pratikleri, artık sadece profesyonel gazeteciler ve medya kuruluşlarının ilgi ve etkinlik alanı olmaktan çıkmaya başlamış ve herkesin edinemediği oldukça pahalı ekipmanlar artık küresel ölçekteki bir kitleye haber sunabilmek açısından gerekli olma vasfını yitirmiştir (Limbourg, 2014, 12). Bu yeni teknolojiler ile karakterize olan iletişim ortamı, kuşkusuz uluslararası yayıncılığa ve uluslararası yayıncı kuruluşların stratejilerine ve standartlarına da birtakım dönüştürücü etkilerde bulunmuştur.

Zöllner'e göre (2011); Arap Baharı olarak nitelendirilen ve Tunus, Mısır, Libya gibi yerlerde gerçekleşen protesto hareketlerinin Facebook ve Twitter gibi sosyal ağlar üzerinden organize olabilmesi, iletişim ve kitle örgütlenmelerinde devletsiz, merkezsiz ve mekânsız sistemlerin giderek artan önemini ortaya koymuştur. $\mathrm{Bu}$ tarz Web 2.0 uygulamalarının diyalojik fonksiyonları aracılığıyla ulus ötesi dönemin yeni "ulusları" olarak nitelendirilebileceği dahi söylenebilmektedir. Dolayısıyla bu yeni tablo, kamu diplomasisi anlayışının ve uluslararası yayıncılığın yeni bir kavramsallaştırması için çağrı niteliği taşımaktadır. Bu kapsamda uluslararası yayıncı kuruluşların web sitelerine Facebook ve Twitter gibi uygulamaları sadece bir eklenti olarak koymalarının ötesinde bunların uluslararası yayıncılık için ne tür bir enstrüman olabileceği ya da ne tür bir işlevsellikle kullanılabileceği sorusu karşımıza çıkmaktadır. Bu tarz sorular, esasında internet ve sosyal medyanın yeni bir kamusal alana zemin hazırlayıp hazırlamadığı noktasına odaklanmaktadır. Bu denklem içinde Castells'e referansla; kamu diplomasisi fikrinin arkasındaki temel motivasyon, farklı toplumlar ve onların kültürleri arasında anlayıș ve uzlaşmanın paylaşılması umuduyla bir diyalogun geliștirilmesi olarak belirmektedir. Bu düşünce ise çeşitli kökenleri, farklı değerleri ve sıklıkla çatışan çıkarlarına rağmen farklı seslerin duyulabildiği yeni bir tür kamusal alan ya da küresel sivil toplumu inşa etmekle optimum biçimde hayata geçirilebilir. Bu perspektiften bakıldığında; bir tarafta kamu diplomatları ve uluslararası yayıncıların, diğer tarafta ise yerel aktivist hareketler ile diğer sivil toplum unsurlarının böyle bir vaadi yerine getirebilecek ortak bir zemini henüz yeterince paylaşıp paylaşmadığı şüpheli gözükmektedir. Zira, imparatorluk geleneği reflekslerini ve propaganda misyonunu kolayca aşabilmenin zorluğuna koşut olarak; gelişip serpilebilmek için gerçek anlamda bir kamu diplomasisi ve uluslararası yayıncılık hizmetine bu denli ihtiyaç duyan bir küresel sivil toplum da henüz dünyada olması arzulanan diyalojik denklemin bir parçası hâline gelememiștir.

Yeni iletişim ortamının uluslararası yayıncılık açısından getirdiği bir başka değișim ve genişleme alanı da sosyal medyanın, uluslararası yayıncı kuruluşlara yurt dışında çok daha fazla izleyiciye ve ayrıca gençler ve kadınlar gibi daha spesifik hedef kitlelere daha fazla ulaşabilme noktasında daha önce benzeri görülmemiş 
biçimde bir alan açması olmuştur. Öte yandan, sosyal ağların bir başka avantajı da yeni program formatları geliştirebilmek için potansiyeller taşıması, haber ajansları için alternatif enformasyon kaynakları sağlaması ve gazeteciler için yeni araştırma araçları üretmiş olmasıdır (Limbourg, 2014, 12).

Sosyal medya çağında uluslararası yayıncılar ve izleyiciler arasındaki ilişkinin dönüșmesi de bir başka belirgin değișim alanına karşılık gelmektedir. Öyle ki; kullanıcı üretimi/türevli içerik özelliği sayesinde her bir izleyici kendi içeriğini üretebilme ve kamusal dolaşıma sokabilme kapasitesine sahip olduğu gibi; uluslararası yayıncı kuruluşun üretimine de katkı sağlayabilmektedir. Bu değişime diğer tarafından bakıldığında ise izleyicilerin, yayıncıların orijinal mesajını yaratıcı biçimlerde işleyebilmesi veya yayıncı kuruluşun hedef ve bağlamından kopartarak çarpıtabilmesi de yeni olanaklar dahilinde sıralanabilmektedir. Dolayısıyla bu yeni dünyaya dahil olabilmenin yollarından biri de ürettiği içerik son kullanıcıya ulaşmadan önce yayıncının gerçekte bu içerik üzerindeki tam kontrolünü kaybedebilecek bir içerik üreticisi olarak kavranmasıdır. Uluslararası yayıncılık açısından da geçerlilik taşıyan bu duruma rağmen yayıncı kuruluşlar, düzenli içeriklerinin en azından bir kısmının kolaylıkla daha kullanışlı ve paylaşılabilir biçimde olmasını sağlamakla yükümlüdürler. Bu bağlamda, bir kamu diplomasisi aktörünün uluslararası haber akışlarını, örneğin YouTube üzerinden erişilebilir hâle getirmesi, hedef kitle açısından söz konusu içeriklere ulaşımı üst düzeylere çıkartabilecektir (Cull, 2008, 52).

Öte yandan, sosyal medya etrafında örülü bu teknolojik ilerleme öylesine hızlı bir biçimde yol almaktadır ki, artık uluslararası yayıncı kuruluşların sosyal ağlarda yer alması ya da mobil uygulamalar geliştirerek ceplere girmesi de aynı hızla "sıradan" bir uygulama niteliğine dönüşebilmektedir. Bu noktada, tecimsel yayıncı kuruluşlarda olduğu gibi uluslararası yayıncı kuruluşlar da yeni teknolojik imkânlara kısa sürede uyumlanma baskısını yoğun biçimde tașımaktadır. Örneğin, bu dijital ve sosyal sahada bir başka eğilim, The Guardian, The New York Times ve The Economist gibi medya kuruluşlarının Apple Watch uygulamaları ile bireylere çarpıcı bir fotoğraf ve başlıkla haber uyarısı göndermesi olarak görünüm kazanmaktadır (Ergüler, 2015). Bir bakışta gazetecilik (glance journalism) olarak da tanımlanan bu uygulama, uluslararası yayıncı kuruluşlar açısından da yakın zamanda bir açılım sahası olarak işlev görebilir.

Burada esas itibariyle; hem uluslararası yayıncı kuruluşların hedef kitlelere ulaşımı konusunda hem de izleyicilerin bu kuruluşlara erişimi sürecinde yeni yol ve yöntemlerin giderek artan kullanımı sorusu karşımıza çıkmaktadır. Öyle ki; internet, uydular, sosyal medya, bloglar, mikro bloglar, mobil teknolojiler, akıllı telefon ve akıllı saatler gibi medya kullanımı ve alımlamasının giderek mobil hâle gelen doğası, belirgin bir format veya dağıtım teknolojisi kullanımını artık yeterli olma durumundan çıkarmaktadır. İşte bu yeni durum, en temelde hedef kitleleri edilgen ya da tek taraflı mesaj enjekte etmeye elverişli bir "kitle" olarak değerlendiren anlayışa yönelik meydan okumayı da beraberinde getirmiştir. Bu noktada; dünya ölçeğinde diasporik ağlar içinde dağılmış nüfus gruplarıyla iletişim sürecinde güvenilirlik sorunlarının belirmesi ihtimali, düne göre daha fazla olası hâle gelmiştir. Çünkü enformasyon ve haberler, sayısız iletişim kanalı aracılığıyla doğrulama süreçlerine tabi tutulabilmektedir (Price ve diğerleri, 2008, 154). Sosyal medya çağının uluslararası yayıncılık pratiğine getirdiği zincirleme değişimlerin özünde 
yatan bu olgu; uluslararası yayıncı kuruluşları, yayınlarını en son gelişmelere ayak uyduracak şekilde dijitalize-mobilize etme ve kişiselleștirme noktasında hareketlendirmektedir. Bir başka ifadeyle, uluslararası yayıncılığın ve yayıncı kuruluşların kendilerini sürekli akış hâlinde olan bu dönüşüme uyumlu hâle getirme gereksinimi, kaçınılmaz ve varoluşsal bir zorunluluk olarak ortaya çıkmaktadır.

\section{Sonuç}

Küreseldünyanın çokaktörlü biryapıya evrildiği günümüzkonjonktüründeyayıncılık, medya ve iletişim alanı da internet ve sosyal ağların ördüğü yeni bir dijital sosyopolitik ve sosyo-kültürel mekânı șekillendirmeye başlamıştır. Görece daha yakın zamanlarda bu örgüye, oldukça hızlı sayılabilecek ritimlerde mobil teknolojiler ve bunlardan türeyen uygulamalar da güçlü biçimde dahil olmuştur. Medya ve iletişim alanındaki diğer aktörler gibi uluslararası yayıncılık da içinde salınım hâlinde olduğu bu akışkan yapının uyum ve değişim baskılarını yoğun biçimde hissetmeye başlamış ve yayıncı kuruluşlar kendini bu yeni iletişim ortamına çeşitli formlarda eklemlemeye başlamışlardır. Örneğin, uluslararası yayıncı kuruluşların web saylarına kuş bakışı bir göz atıldığında; bu alandaki bütün aktörlerin çeşitli sosyal medya platformlarında bütünleşik bir iletişim yönetimi gerçekleştirme motivasyonu içinde oldukları görülmektedir.

İnternet, sosyal medya ve bunlarla eklemlenen mobil teknolojiler, hem ulusal hem de uluslararası bağlamda merkezkaç kuvvetlerin haber, içerik ve uygulama üreticisi ve dağıtıcısı olma anlamında önemli bir aktör konumuna eriştiği bir medya ve iletişim ortamının sınırlarını her geçen gün genişletmektedir. Örneğin sosyal medya platformları aracılığıyla kullanıcıların içerik üretebilmesi ve bunları yayabilmesi; bireylerin, toplulukların ve grupların bir anda potansiyel olarak uluslararası yayıncı statüsüne gelebilmesi ya da bu anlamda uluslararası arenada önemli etkiler uyandırabilmesi gibi kayda değer potansiyeller doğurmuştur. Öte yandan, bu yeni ortam, uluslararası yayınların içeriğine yönelik çok geniş bir yelpazede doğrulama mekanizmalarını hedef kitlelerin önüne sermiștir. Böyle bir imkân ve potansiyeller zinciri; en genel anlamda uluslararası yayıncılığın daha çok ilk dönemleriyle özdeşleşen tek yönlü mesaj sunumu üzerine kurulu pratik ve değerlerini, çift yönlü ve hatta çok yönlü-çok aktörlü-çok ortamlı bir süreç olarak tasarlanması gerekecek şekilde dönüştürmeye başlamıştır.

Öte yandan, uluslararası yayıncıların içinde iş gördüğü bu yeni çerçeve, bu kuruluşların ülkelerinin diş politika hedeflerinden ve sorunlara ilişkin temel yaklaşımlarından keskin bir kopuşu da imlemez. Zira, bir kamu diplomasisi enstrümanı olarak işlev kazanan uluslararası yayıncılığın doğasında böyle bir motivasyon temel itici güçlerden birini oluşturmaktadır. Ancak uluslararası yayıncılığın; gazeteciliğin dengelilik, farklı bakış açılarını gösterme, doğruluk, çatışmayı tartışmaya dönüştürme, diyalog geliştirme gibi birtakım kodlarından tamamen yalıtılmış biçimde icrası da 21. yüzyılın mevcut iletişim ortamıyla uyuşmadığı gibi o yayıncı kuruluşu da anakronik bir konuma kolaylıkla düşürecektir. Üstelik kullanıcıların daha önce hiç olmadığı kadar etkinlik kazandığı bu yeni iletişim ortamında bu tarz uluslararası yayın kuruluşlarının saygınlık, güvenilirlik ve inanılırlık gibi eksenlerde inşa etmeye çalıştıkları imajları da çok hızlı biçimlerde müstehzi ve pejoratif biçimlerde ağ ortamında yayılabilmektedir. Dolayısıyla uluslararası yayıncılığın devletlerin dış politika hedefleriyle ilişkisi, görece daha rafine biçimde ve mümkün olduğunca yukarıda sıralanan gazetecilik kodları 
etrafında kurulmalıdır. Ayrıca, uluslararası yayıncı kuruluşlar; kültürel geliştirme, diyalog sağlama, iş birlikleri geliştirilmesine katkı sağlama, farklı kültürleri ve altkültürel grupları tanıtma şeklinde sıralanabilecek sivil alanlarda zaten mevcut olan yayınlarına daha fazla yoğunluk kazandırabilirler. Bu tarz yayınlar, farklı kültürlere mensup hedef kitlelerin ilgisini daha fazla çekerek kültürlerarası diyalog işlevini ön plana çıkartabileceği gibi; farklı ülkelerdeki akraba topluluklar ya da ortak kültür ve aidiyet bağlarına sahip gruplar açısından tutunum ve aidiyet zeminini daha da güçlendirebilir. Sonuç olarak; farklı türden işlev ve yükümlülükleriyle âdeta bir sarkacın hareketlerini andıran uluslararası yayıncılık, aynı zamanda bu işlevler arasındaki geçişkenliğin oldukça hızlı ve kimi zaman açık kimi zaman da örtük biçimde olması ile karakterize olmaktadır. Bu salınım hareketinin uğrak noktalarında propaganda, kamu diplomasisi ve nesnelsek-dengelilik-çok yönlülük-doğruluk gibi kutup başları sıralanabilmektedir.

\section{Kaynakça}

Amerikanın Sesi. Erişim: 05 Eylül 2015, http://www.amerikaninsesi.com/info/bizkimiz/1920.html.

Atewolara-Odule, O. A., Ojo, T. O. ve Akinreti, Q. (2016). The Roles of International Broadcasting in Revamping Nigeria's Public Image, Implications for Nationalism Among Nigerian Youths. Kuwait Chapter of Arabian Journal of Business and Management Review, 6(3), 13-31.

Brodsky. L. N. (2010). Democracy Across The Airwaves, The Strategic Work OfAmerican International Broadcasting in Azerbaijan and Iran. Doktora tezi, The Fletcher School of Law and Diplomacy, Medford.

Bumpus, B. ve Skelt, B. (1984) Seventy Years of International Broadcasting (Communication and Society 14). Paris: UNESCO.

Castells, M. (2005). The Network Society: From Knowledge to Policy. M. Castells ve G. Cardoso (Ed.). The Network Society, From Knowledge to Policy (3-21). Washington: Johns Hopkins Center for Transatlantic Relations.

Codding, G. (1959). Broadcasting without Barriers. Netherlands: UNESCO.

Cull, N. J. (1995) Selling War: The British propaganda campaign against American "neutrality" in World War II. Oxford: Oxford University Press.

Cull, N. J. (2008). Public Diplomacy, Taxonomies and Histories. The Annals of the American Academy of Political and Social Science, 616, 31-54.

Cummings, R. H. (2009). Cold War Radio. The Dangerous History of American Broadcasting in Europe, 1950-1989. Jefferson:, McFarland and Company.

Demirkıran, C. (2008). Uluslararası Televizyon Yayıncılığının Tarihsel Gelişim Süreci, Fransa TV5 MONDE ile Türkiye TRT-INT ve TRT TÜRK Karşılaştırmalı Incelemesi. Doktora tezi, İstanbul Üniversitesi, İstanbul.

Devran, Y. (2015). Yeni Türkiye'nin Küresel Sesi TRT World, Fırsatlar ve Güçlükler. E-journal of Intermedia, 2(2), 281-294.

Douai, A. (2009). International Broadcasting and The Management of Foreign Public Opinion, The Case of Al-Hurra Television in The "Arab Street". Doktora tezi, The Pennsylvania State University, Pennsylvania. 
Ergüler, D. (2015). Akıllı Saatler Habercilik Dünyasını Nasıl Etkileyecek. Erişim: 18 Mayıs 2015, http://p24blog.org/yazarlar/901/akilli-saatler-habercilik-dunyasininasil-etkileyecek.

Limbourg, P. (2014). Social Media-Chances and Challenges for International Broadcasting. Global-ICT, 12-13.

Norihiro, T. (2009). International Television Broadcasting in East Asia, Current Situation and Challenges. NHK Broadcasting Studies, 7, 21-53.

Ojomo, O. ve Olomojobi, O. (2012). International Broadcasting, National Security and the Public's Right to Know. Benin Mediacom Journal, 5, 43-53.

O'Keeffe, A. ve Oliver A. (2010). International Broadcasting and Its Contribution to Public Diplomacy. Lowy Institute for International Policy.

Price, M. (2003). Public Diplomacy and the Transformation of International Broadcasting. Cardozo Arts and Entertainment Law Journal, 21(1), 51-85.

Price, M., Haas, S. ve Margolin, D. (2008). New Technologies and International Broadcasting: Reflections on Adaptations and Transformations. The Annals of the American Academy of Political and Social Science, 616(1), 150-172.

Ronalds, F. S. (1971). The Future of International Broadcasting. The Annals of the American Academy of Political and Social Science, 398, 71-80.

Powers, S. M. ve Youmans, W. (2012) A New Purpose for International Broadcasting, Subsidizing Deliberative Technologies in Non-transitioning States. Journal of Public Deliberation, 8(1), 1-14.

Radio Free Europe/Radio Liberty. Erişim: 05 Eylül 2015, http://www.rferl.org/info/ mission/169.html.

Rawnsley, G. D. (2016). Introduction to "International Broadcasting and Public Diplomacy in the 21st Century". Media and Communication, 4(2), 42-45.

Rawnsley, Garry D. (1996). Radio Diplomacy and Propaganda. The BBC and VOA in International Politics, 1956-64. Houndmills: Macmillan Press.

Rawnsley, G. D. (1999). The BBC External Services and the Hungarian Uprising,1956. G. D. Rawnsley (Ed.). Cold-War Propaganda in the 1950 (165-181). Houndmills: Macmillan Press.

Richter, C. (2008). International Broadcasting and Intercultural Dialogue: Deutsche Welle in the Arab World. Arab Media \& Society, 6, 1-11.

Risso, L. (2013) Radio Wars: Broadcasting in the Cold War. Cold War History, 13(2), $145-152$

Si, S. (2014). Expansion of International Broadcasting. The Growing Global Reach of China Central Television. Oxford: Reuters Institute for the Study of Journalism.

The Edward R. Murrow Center of Public Diplomacy. Erişim: 01 Eylül 2015, http:// fletcher.tufts.edu/Murrow/Diplomacy.

United States Broadcasting Board of Governors. Erişim: 05 Eyül 2015. http://www. bbg.gov/wp-content/media/2012/01/BroadcastingAct.pdf.

Taylor, P. M. (2003). Munitions of the Mind. A History of Propaganda from The Ancient World to The Present Era. Manchester: Manchester University Press. 
TRT World. Erişim: 15 Ekim 2018, https://www.trtworld.com.

Türkiye'nin Sesi Radyosu. Erişim: 15 Ekim 2018, http://www.turkiyeninsesiradyosu. com/ ?r=site/content\&id=32

Weed, M. C. (2016). U.S. International Broadcasting, Background and Issues for Reform (R43521). Washington: Congressional Research Service.

Wood, J.(2008). History of International Broadcasting Volume 1. London: The Institution of Engineering and Technology.

Zöllner, O.(2011).InternationalBroadcastingin theSocialNetworkEra, NewAllegiances in Deterritorialized Space Call for New Public Diplomacy. Erişim: 22 Haziran 2011, http://publicdiplomacymagazine.com/international-broadcasting-inthe-social-network-era-new-allegiances-in-deterritorialized-space-call-fornew-public-diplomacy/. 